\title{
Niveles de bienestar psicológico en futbolistas de categorias sub16 - sub19
}

\section{Levels of psychological well-being in category footballers U16 - U19}

\author{
Hakan Akdeniz ${ }^{1 \mathrm{a}}$ Özlem Keskin, ${ }^{2}$ Onur Kavi ${ }^{3}$ \& Alim Can Kaya ${ }^{4}$ \\ Kocaeli University, Sports Sciences Faculty Recreation Department, Turkey ${ }^{1}$ \\ Sinop University, Faculty of Sports Sciences, Turkey ${ }^{2}$ \\ Kocaeli University, Sports Sciences Faculty, Turkey ${ }^{34}$ \\ (iD) ORCID ID: https://orcid.org/0000-0001-8171-1821 ${ }^{1}$ \\ (iD) ORCID ID: https://orcid.org/0000-0003-0223-5914² \\ (iD) ORCID ID: https://orcid.org/0000-0002-9307-744X 3 \\ (iD) ORCID ID: https://orcid.org/0000-0003-2121-1352
}

Recepción: 08 de febrero de 2021

Aceptación: 06 de setiembre de 2021

\begin{abstract}
This study was performed with the aim of investigating the psychological well-being levels of adolescent sportmen in accordance with a number of variables by using the general survey model. The target population of the study composed of 196 sportmen who played soccer for youth setup of amateur football club located in Kocaeli. Within the scope of the study, personal information form and Psychological Well Being Scale were used as data collection tools. In testing of the hypothesis, Pearson Correlation and One-way ANOVA was exerted. In this the study, a significant difference was observed by means of sub-dimensions that can be listed as autonomy, environmental mastery, personal growth, positive relations with others, purpose in life and self-acceptance $(\mathrm{p}<0,05)$. it can be commented that the performance of adolescent footballer's alternates in accordance with their psychological well-being levels in terms of different teams. When the performance of adolescent footballers was evaluated according to psychological well-being levels, no significant difference was observed ( $p>0,05)$. As a result of league levels, league positions and monthly a significant difference was observed $(\mathrm{p}<0,05)$. When the collected data were interpreted, it can be stated that performance and psychological well-being levels of sportsmen show and alteration with regard to league levels, league positions, and monthly household income.
\end{abstract}

Keywords: Football, psychological wellbeing, youth setup, sport, performance, adolescence

\section{Resumen}

Este estudio se realizó con el objetivo de investigar los niveles de bienestar psicológico en deportistas adolescentes de acuerdo con una serie de variables utilizando el modelo de encuesta 
general. La población objetivo del estudio se compone de 196 deportistas que jugaron al fútbol para el club de fútbol juvenil amateur ubicado en Kocaeli (Turquía). Dentro del alcance del estudio, se utilizaron el formulario de información personal y la Escala de Bienestar Psicológico como herramientas de recolección de datos. Al probar la hipótesis, además, se aplicó el análisis ANOVA unidireccional. En este estudio, se observó una diferencia significativa mediante subdimensiones que se pueden catalogar como autonomía, dominio ambiental, crecimiento personal, relaciones positivas con los demás, propósito en la vida y autoaceptación ( $\mathrm{p}<0.05$ ). Se puede comentar que el desempeño de los futbolistas adolescentes suplentes de acuerdo con sus niveles de bienestar psicológico en función de los diferentes equipos. Cuando se evaluó el desempeño de los deportistas adolescentes de acuerdo con los niveles de bienestar psicológico, no se observó diferencia significativa ( $p>0.05$ ). Como resultado de los niveles de liga, posiciones de liga y mensual se observó una diferencia significativa ( $\mathrm{p}<0.05)$. Cuando se interpretaron los datos recolectados, se puede afirmar que el rendimiento y los niveles de bienestar psicológico de los deportistas muestran una alteración con respecto a los niveles de liga, posiciones de liga e ingresos familiares mensuales.

Palabras clave: Fútbol, bienestar psicológico, configuración juvenil, deporte, rendimiento, adolescencia.

\section{Introduction}

Positive psychology is not a new concept. Throughout the ages, all thinkers have tried to understand the importance of a good life and a moral and virtuous life. In Ancient Greece, for example, Aristotle talked about the importance of a good life for the individual and society in his work Nicomachean Ethics; he stated that the highest good for all humanity is happiness (Seligman, 2002).

Psychology has dealt with the concept of "well-being" mainly with two main approaches: "hedonic", which is based on the balancing of positive and negative emotions and the happiness of the individual, and "eudaimonic", which is based on the individual's understanding of how to be well. The hedonic approach is also called subjective well-being and is defined as the individual experiencing positive emotions frequently, negative emotions less frequently, and getting high satisfaction from life (Ryan \& Deci, 2001). It has been demonstrated that psychological disorders such as depression, anxiety and stress can benefit from participation in physical activity (Hunt-Shanks et al.,2009).

Adolescence is the situation in which the person biologically, physically, sexually and mentally grows between 12 and 14 years. The person takes the step to be an adult at the end of the adolescence period. Since the young individuals grow in that period, they are directed to sports. They are also provided to commune with the sports to be healthier. Positive psychology 
is a fact that is composed of various findings and different parts of psychology by evaluating the correct parts of the attitudes of the individuals (Yavuzer, 2013).

Positive results are obtained as the result of being directed the players in adolescence period to the sports. Personal well-being emerges as a result of being in positive social relationships and recreational events that provide to derived different pleasures (Shuster et al., 2004). Sports is a significant activity that creates motivation for the essential requirements of the young people in the adolescence period. To decide by considering the development and growth of the child in adolescence period is a more positive approach to participating in the sports (Eryilmaz, 2010).

While a positive and significant relationship between psychological variables and physical activity may be interesting for mentally healthy individuals, it appears to be stronger for the psychological community (Biddle, et al, 2001). Sports activities provide positive effects to the human body (Ustun et al., 2020). Both psychological and physiological benefits can be received by being participated in sports activities by the children in the development period. Sports activities contribute to body development and growth rate of children. Moreover, the growth hormone starts to secrete more during the sports activities; this is because the children who play sports seem like physically developed more than other children. Sports activities increase the self-confidence and provide the progress of relationships with other children. Therefore, the child learns how the friendship relationship is established (Gunduz, et al., 2012).

Self-esteem is one's own judgments about feeling proud, valuable, effortful, active, and successful. It is an emotional state that emerges as a result of individuals' judgment and evaluation of themselves as a complex (Bayazit et al., 2020). In addition, psychological wellbeing includes the individual's positive perception of himself, being satisfied with himself even when he is aware of his limitations, developing safe and warm relationships with others, shaping the environment to meet individual needs and wishes, acting autonomously and independently, having a purpose and meaning in life, being aware of his capacity. It reflects the fact that it is and tries to develop this capacity (Keyes, Shmotkin \& Ryff, 2002).

Therefore, this process can positively affect the career development, psychological health and well-being of the athletes. In addition, psychological well-being refers to the subjective well-being, life satisfaction and happiness of the individual's positive evaluations of his/her past life or himself "self-acceptance", the feeling of constantly growing and developing as an individual "individual development", the belief that the individual's life is meaningful and purposeful "life purpose", warmth and trust in interpersonal relationships "positive relationships with others", the individual's capacity to effectively direct the life around him in 
line with his wishes and needs "environmental dominance", and a sense of self-determination "autonomy" (Keyes, Shmotkin, \& Ryff, 2002). The individual with a high level of psychological well-being tends to learn about himself and what is going on around him. So, emotional intelligence shows a person as a detailer (Pehlivan et al., 2005). Since the emotional intelligence causes to feel better, it may be in a relationship with the psychological well-being (Onur et al., 2015).

In terms of the relationship between physical and mental health, the evidence reveals that physical activity can be used as an adjunctive therapy in mental health treatment (Scully, et al, 1998). It can be ensured individuals in adolescence period to have a better mood by the sports. Cognitive, emotional and social training of the athlete is also a special research area and the major branch of the sports psychology. The psychological training that includes applicable method and techniques is an irrevocable training method in both individual and team sports by ideocratic concepts and idioms (Ryan \& Deci, 2001). Therefore, it is known that participation in sports activities is one of the factors that can meet the desire of the individual to feel good spiritually and to enjoy life.

\section{Methodology}

\section{Study design}

The research was performed with relational screening model. Relational screening model is expressed as the research model in which the presence or degree of the change between two or more than two variables (Karasar, 2003).

\section{Study sample}

Working group of this research was composed of 196 team players who perform in U16U17-U19 age groups of Dil İskelesi Sports Club, Dilovası Municipality Sports Club, Çayırova Sports Club, Gebze Sports Club. 56 players from U16 age group; 61 players from U17 age group; 79 players from the U19 age group were included in the research.

\section{Data collection tools}

The data on the psychological well-being of footballers were analyzed by 'Psychological WellBeing Scale and Demographic Information Form'. This scale was developed by Ryff and adapted to Turkish by different investigators (Cirhinlioglu, 2006; Akin, 2008). The form of Psychological Well-Being Scale with 42 items for 6 dimensions was used in this research. The original of the scale is composed of 6 dimensions and 84 items. In the original form of the scale, the reliability coefficient of the scale was found as 86 for autonomy sub-scale; 90 for 
environmental domination sub-scale; 93 for self-acceptance sub-scale; 91 for the positive relationships with others; 90 for life purposed sub-scales; 74 for the personal development.

The long form of Psychological Well-Being Scale was adapted to Turkish by Akın. Long form's adaptation to Turkish was performed by the explanatory factor analysis that was applied to the data obtained from 791 university students. KMO sample conformance coefficient was found as .766; Barlett x2 value was computed as 52619,744 (Demirci,. 2012). Confirmatory factor analysis was utilized for adapting the short form. Confirmatory factor analysis approves that Psychological Well-Being Scale with the short form have pretty fit values $\left(x^{2}=2689,13, \mathrm{df}=791, \mathrm{p}=0,00000, \mathrm{RMSEA}=.048, \mathrm{NFI}=.92, \mathrm{NNFI}=94, \mathrm{CFI}=.95, \mathrm{IFI}=\right.$ .95 , RFI=.92, GFI=.90, ve SRMR=.048). Internal consistency coefficient of Psychological Well-Being Scale with the short form is .87. All the differences between factor scores higher than 27\% and lower than 27\%. All these outcomes pointed out that Psychological Well-Being Scale with 42 items is statistically sufficient (Akın et al., 2012).

\section{Data analysis}

Data analysis SPSS 21 packaged software was used to analyze the data obtained at the end of the data collection process. Frequency and percentage values of the general information on the participants were received. Single factorial variance analysis (One-Way ANOVA), Correlation test and Tukey, LCD tests were used to be tested the hypotheses.

\section{Results}

This study was conducted to evaluate the psychological well-being levels of adolescent footballers in terms of club, variables, term of the license. The results obtained are presented in tables below.

Table 1

Pearson Correlation Results between the variables

\begin{tabular}{llccccccccc}
\hline & & $\mathrm{N}$ & Mean & Std.Dev & 1 & 2 & 3 & 4 & 5 & 6 \\
\hline 1 & Autonomy & 196 & 33,13 & 8,57 & 1 & & & & & \\
2 & $\begin{array}{l}\text { Environmental } \\
\text { mastery }\end{array}$ & 196 & 32,96 & 8,44 &, $730^{* *}$ & 1 & & & & \\
3 & $\begin{array}{l}\text { Individual } \\
\text { Development }\end{array}$ & 196 & 32,14 & 7,62 &, $684^{* *}$ &, $757^{* *}$ & 1 & & & \\
4 & $\begin{array}{l}\text { Positive } \\
\text { Relationship } \\
\text { with others }\end{array}$ & 196 & 36,90 & 5,93 &, $608^{* *}$ &, $677^{* *}$ &, $700^{* *}$ & 1 & & \\
5 & $\begin{array}{l}\text { Life goals } \\
6\end{array}$ & 196 & 32,90 & 9,90 &, $734^{* *}$ &, $762^{* *}$ &, $690^{* *}$ &, $640^{* *}$ & 1 & \\
& $\begin{array}{l}\text { Self- } \\
\text { acceptance }\end{array}$ & 196 & 32,61 & 6,72 &, $685^{* *}$ & $, 700^{* *}, 573^{* *}$ &, $590^{* *}$ &, $784^{* *}$ & 1 \\
7 & $\begin{array}{l}\text { Psychological } \\
\text { Well Being }\end{array}$ & 196 & 200,82 & 40,88 &, $869^{* *}$ &, $900^{* *}$ &, $850^{* *}$ &, $796^{* *}$ &, $905^{* *}$ &, $836^{* *}$ \\
& \begin{tabular}{l} 
Scales \\
\hline
\end{tabular} & & & & & & & \\
\hline
\end{tabular}

Table above shows the correlation values based on the sub-dimensions $\left(* * \mathrm{p}<0.01,{ }^{*} \mathrm{p}<0.05\right)$ 
Table 2

One Way ANOVA results by team variable

\begin{tabular}{|c|c|c|c|c|c|c|c|}
\hline & $\mathbf{n}$ & & $x-$ & Ss & $\mathbf{F}$ & $\mathbf{P}$ & TUKEY \\
\hline \multirow{5}{*}{ Autonomy } & Dilovası Belediye & 60 & 32,58 & 4,38 & \multirow{5}{*}{83,782} & \multirow{5}{*}{,000 } & $1-2$ \\
\hline & Çayırova Spor & 56 & 26,42 & 6,11 & & & $1-3$ \\
\hline & Dil iskelesi Spor & 19 & 26,36 & 4,01 & & & $1-4$ \\
\hline & Gebze Spor & 61 & 41,93 & 6,74 & & & $2-4$ \\
\hline & Total & 196 & 33,13 & 8,57 & & & $3-5$ \\
\hline \multirow{6}{*}{$\begin{array}{l}\text { Environmental } \\
\text { Mastery }\end{array}$} & Dilovas1 Belediye & 60 & 30,60 & 6,18 & \multirow{5}{*}{49,442} & \multirow{5}{*}{, 000 } & \\
\hline & Çayırova Spor & 56 & 28,50 & 5,45 & & & $1-4$ \\
\hline & Dil iskelesi Spor & 19 & 27,47 & 4,38 & & & $2-4$ \\
\hline & Gebze Spor & 61 & 41,09 & 7,75 & & & $3-4$ \\
\hline & Total & 196 & 32,96 & 8,44 & & & \\
\hline & Dilovas1 Belediye & 60 & 30,45 & 6,76 & \multirow{5}{*}{32,960} & \multirow{5}{*}{, 000 } & \\
\hline \multirow{4}{*}{$\begin{array}{l}\text { Individual } \\
\text { development }\end{array}$} & Çayırova Spor & 56 & 27,94 & 5,35 & & & $1-4$ \\
\hline & Dil iskelesi Spor & 19 & 29,21 & 3,88 & & & $2-4$ \\
\hline & Gebze Spor & 61 & 38,59 & 7,00 & & & $3-4$ \\
\hline & Total & 196 & 32,14 & 7,62 & & & \\
\hline \multirow{5}{*}{$\begin{array}{l}\text { Positive } \\
\text { relationship } \\
\text { with others }\end{array}$} & Dilovas1 Belediye & 60 & 36,83 & 5,28 & \multirow{5}{*}{35,794} & \multirow{5}{*}{,000 } & $1-2$ \\
\hline & Çayırova Spor & 56 & 32,92 & 4,22 & & & $1-3$ \\
\hline & Dil iskelesi Spor & 19 & 33,50 & 3,58 & & & $1-4$ \\
\hline & Gebze Spor & 61 & 41,63 & 5,04 & & & $2-4$ \\
\hline & Total & 196 & 36,90 & 5,93 & & & 3-4 \\
\hline \multirow{5}{*}{ Life goals } & Dilovası Belediye & 60 & 27,98 & 5,22 & \multirow{5}{*}{65,639} & \multirow{5}{*}{,000 } & \\
\hline & Çayırova Spor & 56 & 28,76 & 6,30 & & & $1-4$ \\
\hline & Dil iskelesi Spor & 19 & 27,15 & 3,62 & & & $2-4$ \\
\hline & Gebze Spor & 61 & 43,34 & 9,50 & & & $3-4$ \\
\hline & Total & 196 & 32,90 & 9,90 & & & \\
\hline \multirow{5}{*}{$\begin{array}{l}\text { Self- } \\
\text { acceptance }\end{array}$} & Dilovası belediye & 60 & 29,83 & 4,52 & \multirow{5}{*}{67,606} & \multirow{5}{*}{,000 } & \\
\hline & Çayırova spor & 56 & 29,58 & 5,01 & & & $1-4$ \\
\hline & Dil iskelesi spor & 19 & 27,52 & 4,43 & & & $2-4$ \\
\hline & Gebze spor & 61 & 39,70 & 4,73 & & & 3-4 \\
\hline & Total & 196 & 32,61 & 6,72 & & & \\
\hline \multirow{5}{*}{$\begin{array}{l}\text { Psychological } \\
\text { Well Being } \\
\text { Scales }\end{array}$} & Dilovası belediye & 60 & 188,28 & 19,16 & \multirow{5}{*}{91,349} & \multirow{5}{*}{,000 } & \\
\hline & Çayırova spor & 56 & 174,16 & 19,54 & & & $1-2$ \\
\hline & Dil iskelesi spor & 19 & 171,38 & 8,87 & & & $1-4$ \\
\hline & Gebze spor & 61 & 246,31 & 38,54 & & & $2-4$ \\
\hline & Total & 196 & 200,82 & 40,88 & & & 3-4 \\
\hline
\end{tabular}

There was found a significant difference in all of the sub-dimensions based on ANOVA and Tukey table test results $(\mathrm{p}<0,05)$. So, we can say that the teams differ in autonomy, environmental mastery, individual development, positive relationships with others, life goals, self-acceptance, psychological well-being scales. 
Table 3

One Way ANOVA results based on league level variable

\begin{tabular}{|c|c|c|c|c|c|c|c|}
\hline & & $\mathbf{n}$ & $x-$ & ss & $\mathbf{F}$ & $\mathbf{P}$ & LCD \\
\hline \multirow{4}{*}{ Autonomy } & U-16 & 56 & 31,32 & 6,71 & \multirow{4}{*}{6,660} & \multirow{4}{*}{,002 } & \\
\hline & U-17 & 61 & 36,34 & 8,65 & & & $1-2$ \\
\hline & U-19 & 79 & 31,93 & 9,08 & & & $2-3$ \\
\hline & Total & 196 & 33,13 & 8,57 & & & \\
\hline \multirow{4}{*}{$\begin{array}{l}\text { Environmental } \\
\text { mastery }\end{array}$} & U-16 & 56 & 31,28 & 7,61 & \multirow{4}{*}{3,608} & \multirow{4}{*}{,029 } & \multirow{4}{*}{$1-2$} \\
\hline & U-17 & 61 & 35,24 & 9,07 & & & \\
\hline & U-19 & 79 & 32,39 & 8,22 & & & \\
\hline & Total & 196 & 32,96 & 8,44 & & & \\
\hline \multirow{4}{*}{$\begin{array}{l}\text { Individual } \\
\text { development }\end{array}$} & U-16 & 56 & 29,85 & 7,66 & \multirow{4}{*}{6,716} & \multirow{4}{*}{,002 } & \\
\hline & U-17 & 61 & 34,80 & 7,89 & & & $1-2$ \\
\hline & U-19 & 79 & 31,72 & 6,82 & & & $2-3$ \\
\hline & Total & 196 & 32,14 & 7,62 & & & \\
\hline \multirow{5}{*}{$\begin{array}{l}\text { Positive relationship } \\
\text { with others }\end{array}$} & U-16 & 56 & 36,39 & 6,08 & \multirow{5}{*}{2,067} & \multirow{5}{*}{, 129 } & \\
\hline & U-17 & 61 & 38,18 & 6,02 & & & \\
\hline & U-19 & 79 & 36,28 & 5,67 & & & \\
\hline & Total & 196 & 36,90 & 5,93 & & & \\
\hline & U-16 & 56 & 31,19 & 7,50 & & & \\
\hline \multirow[t]{3}{*}{ Life goals } & U-17 & 61 & 35,59 & 10,65 & \multirow{3}{*}{3,453} & \multirow{3}{*}{,034 } & \multirow{3}{*}{$1-2$} \\
\hline & U-19 & 79 & 32,05 & 10,47 & & & \\
\hline & Total & 196 & 32,90 & 9,90 & & & \\
\hline \multirow[t]{5}{*}{ Self-acceptance } & U-16 & 56 & 31,78 & 5,01 & \multirow{4}{*}{1,589} & \multirow{4}{*}{ 207 } & \\
\hline & U-17 & 61 & 33,85 & 7,42 & & & \\
\hline & U-19 & 79 & 32,24 & 7,15 & & & \\
\hline & Total & 196 & 32,61 & 6,72 & & & \\
\hline & U-16 & 56 & 191,83 & 31,02 & \multirow{4}{*}{5,085} & \multirow{4}{*}{,007 } & \multirow{4}{*}{$\begin{array}{l}1-2 \\
2-3\end{array}$} \\
\hline \multirow{3}{*}{$\begin{array}{l}\text { Psychological Well } \\
\text { Being Scales }\end{array}$} & U-17 & 61 & 214,01 & 43,66 & & & \\
\hline & U-19 & 79 & 196,94 & 42,72 & & & \\
\hline & Total & 196 & 200,82 & 40,88 & & & \\
\hline
\end{tabular}

With reference to ANOVA and Tukey test results, there was found a significant difference $(\mathrm{p}<0,05)$ between Autonomy U16-U17 and U17-U19, Environmental Mastery U16U17, Individual development U16-U17 and U17-U19, Life Goals U16-U17 and Psychological Well Being scales U16-U17 and U17-U19. The league level of these teams differs by autonomy, environmental mastery, individual development, life goals and psychological wellbeing scales. 
Table 4

Kruskal-Wallis test results by league ranking

\begin{tabular}{|c|c|c|c|c|c|c|c|}
\hline & & $\mathbf{n}$ & $\mathbf{x}-$ & SS & df & $\mathbf{P}$ & LCD \\
\hline \multirow{4}{*}{ Autonomy } & $1-3$ & 107 & 31,77 & 7,77 & \multirow{4}{*}{2} & \multirow{4}{*}{,028 } & \\
\hline & $4-6$ & 80 & 34,45 & 9,26 & & & $1-3$ \\
\hline & 6 and upper & 9 & 37,55 & 8,90 & & & $1-2$ \\
\hline & Total & 196 & 33,13 & 8,57 & & & \\
\hline \multirow{4}{*}{$\begin{array}{l}\text { Environmental } \\
\text { Mastery }\end{array}$} & $1-3$ & 107 & 32,16 & 7,75 & \multirow{4}{*}{2} & \multirow{4}{*}{239} & \\
\hline & 4-6 & 80 & 33,62 & 9,18 & & & \\
\hline & 6 and upper & 9 & 36,55 & 8,98 & & & \\
\hline & Total & 196 & 32,96 & 8,44 & & & \\
\hline \multirow{4}{*}{$\begin{array}{l}\text { Individual } \\
\text { Development }\end{array}$} & $1-3$ & 107 & 31,31 & 7,79 & \multirow{4}{*}{2} & \multirow{4}{*}{,221 } & \\
\hline & 4-6 & 80 & 33,01 & 7,29 & & & \\
\hline & 6 and upper & 9 & 34,33 & 8,15 & & & \\
\hline & Total & 196 & 32,14 & 7,62 & & & \\
\hline \multirow{4}{*}{$\begin{array}{l}\text { Positive Relationships } \\
\text { with others }\end{array}$} & $1-3$ & 107 & 36,46 & 5,88 & \multirow{4}{*}{2} & \multirow{4}{*}{,328 } & \\
\hline & 4-6 & 80 & 37,17 & 6,03 & & & \\
\hline & 6 and upper & 9 & 39,77 & 5,35 & & & \\
\hline & Total & 196 & 36,90 & 5,93 & & & \\
\hline \multirow{4}{*}{ Life goals } & $1-3$ & 107 & 31,76 & 9,01 & \multirow{4}{*}{2} & \multirow{4}{*}{,260 } & \\
\hline & 4-6 & 80 & 33,95 & 10,76 & & & \\
\hline & 6 and upper & 9 & 37,22 & 11,06 & & & \\
\hline & Total & 196 & 32,90 & 9,90 & & & \\
\hline \multirow{4}{*}{ Self-acceptance } & $1-3$ & 107 & 31,93 & 6,06 & \multirow{4}{*}{2} & \multirow{4}{*}{,259 } & \\
\hline & 4-6 & 80 & 33,18 & 7,44 & & & \\
\hline & 6 and upper & 9 & 35,55 & 7,01 & & & \\
\hline & Total & 196 & 32,61 & 6,72 & & & \\
\hline \multirow{4}{*}{$\begin{array}{l}\text { Psychological well- } \\
\text { being scales }\end{array}$} & $1-3$ & 107 & 195,65 & 36,73 & \multirow{4}{*}{2} & \multirow{4}{*}{, 123} & \\
\hline & 4-6 & 80 & 205,40 & 44,51 & & & \\
\hline & 6 and upper & 9 & 221,00 & 47,13 & & & \\
\hline & Total & 196 & 200,82 & 40,88 & & & \\
\hline
\end{tabular}

About the league ranking, ANOVA and Tukey test results show that there was found a significant difference in autonomy sub-dimension $(\mathrm{p}<0,05)$. We can say that psychological well-being levels vary by the autonomy sub-dimension. 
Table 5

Kuruskal Wallis test results by household income

\begin{tabular}{|c|c|c|c|c|c|c|c|}
\hline & & $\mathbf{n}$ & X- & ss & df & $\mathbf{P}$ & LCD \\
\hline \multirow{5}{*}{ Autonomy } & 1401-2000モ & 49 & 35,36 & 8,11 & \multirow{5}{*}{3} & \multirow{5}{*}{, 018} & \multirow{5}{*}{$\begin{array}{l}1-3 \\
1-2\end{array}$} \\
\hline & 2001-3000€ & 117 & 33,13 & 8,59 & & & \\
\hline & $3001-4000 £$ & 27 & 29,85 & 8,57 & & & \\
\hline & 4001 and upper & 3 & 26,00 & 1,73 & & & \\
\hline & Total & 196 & 33,13 & 8,57 & & & \\
\hline \multirow{5}{*}{$\begin{array}{l}\text { Environmental } \\
\text { mastery }\end{array}$} & $1401-2000 €$ & 49 & 34,59 & 9,05 & \multirow{5}{*}{3} & \multirow{5}{*}{, 128} & \\
\hline & 2001-3000も & 117 & 32,91 & 8,41 & & & \\
\hline & 3001-4000€ & 27 & 31,07 & 7,17 & & & \\
\hline & 4001 and upper & 3 & 25,33 & 3,78 & & & \\
\hline & Total & 196 & 32,96 & 8,44 & & & \\
\hline \multirow{5}{*}{$\begin{array}{l}\text { Individual } \\
\text { Development }\end{array}$} & 1401-2000モ & 49 & 34,22 & 7,61 & \multirow{5}{*}{3} & \multirow{5}{*}{094} & \\
\hline & 2001-3000€ & 117 & 31,86 & 7,71 & & & \\
\hline & 3001-4000 & 27 & 30,00 & 6,98 & & & \\
\hline & 4001 and upper & 3 & 28,66 & 1,52 & & & \\
\hline & Total & 196 & 32,14 & 7,62 & & & \\
\hline \multirow{5}{*}{$\begin{array}{l}\text { Positive } \\
\text { relationship with } \\
\text { others }\end{array}$} & 1401-2000€ & 49 & 38,29 & 6,55 & \multirow{5}{*}{3} & \multirow{5}{*}{093} & \\
\hline & 2001-3000€ & 117 & 36,86 & 5,60 & & & \\
\hline & $3001-4000 £$ & 27 & 35,22 & 5,56 & & & \\
\hline & 4001 and upper & 3 & 31,66 & 7,50 & & & \\
\hline & Total & 196 & 36,90 & 5,93 & & & \\
\hline \multirow{5}{*}{ Life goals } & 1401-2000毛 & 49 & 34,28 & 10,76 & \multirow{5}{*}{3} & \multirow{5}{*}{,98 } & \\
\hline & 2001-3000€ & 117 & 32,69 & 9,78 & & & \\
\hline & 3001-4000 £ & 27 & 32,51 & 8,81 & & & \\
\hline & 4001 and upper & 3 & 22,33 & 2,081 & & & \\
\hline & Total & 196 & 32,90 & 9,90 & & & \\
\hline \multirow{5}{*}{ Self-acceptance } & $1401-2000 €$ & 49 & 33,71 & 6,62 & \multirow{10}{*}{3} & \multirow{5}{*}{, 231} & \\
\hline & 2001-3000€ & 117 & 32,65 & 6,72 & & & \\
\hline & $3001-4000 €$ & 27 & 30,70 & 7,04 & & & \\
\hline & 4001 and upper & 3 & 30,00 & 1,00 & & & \\
\hline & Total & 196 & 32,61 & 6,72 & & & \multirow{6}{*}{$1-3$} \\
\hline \multirow{5}{*}{$\begin{array}{l}\text { Psychological } \\
\text { well-being scales }\end{array}$} & $1401-2000 €$ & 49 & 211,25 & 42,17 & & \multirow{5}{*}{,006 } & \\
\hline & 2001-3000毛 & 117 & 200,12 & 40,27 & & & \\
\hline & 3001-4000€ & 27 & 189,37 & 38,94 & & & \\
\hline & 4001 and upper & 3 & 164,00 & 8,54 & & & \\
\hline & Total & 196 & 200,82 & 40,88 & & & \\
\hline
\end{tabular}

There is a significant difference in autonomy sub-dimension based on ANOVA and Tukey tests $(\mathrm{p}<0,05)$. We can say that the psychological well-being levels vary with the autonomy sub-dimension in monthly household income.

\section{Discussion}

In this research, a statistically positive relationship was found between the psychological well-being scale of football players and their lower dimensions. According to the resulting result, the scale of psychological well-being of footballers was found to have a positively significant relationship between their lower dimensions. Edwards et al. (2005) determined that there is a positive relationship on autonomy, environmental mastery, individual development, 
positive relationships with others life goals and the self-acceptance. Hassmen (2000), analyzed the relationship between physical activity frequency and the psychological well-being. A relationship was found between psychological well-being and the regular exercises. Scully et al. (1998) performed a literature review and reported that the presence of the relationship exercises and the psychological well-being. Dogan (2006) aimed to find the factors that affect the psychological well-being. It is found that the participation frequency in physical activity has an effect on the psychological well-being. It can be said that the regular training positively affects the psychological well-being of the footballers. Besides, Ar1 et al. (2020) there was a positive correlation between mindfulness and life satisfaction.

Anova and Tukey test found a significant difference in all the sub-dimensions $(\mathrm{p}<0,05)$. Autonomy, environmental mastery, individual development, positive relationships with others, life goals, self-acceptance and psychological well-being scales differ in this circumstance. There has not encountered with findings that are equal or opposite to our findings in the literature. This is because any example could not be given.

There was not found a significant difference in any of the sub-dimensions based on ANOVA and Tukey test results by the status variable $(p>0,05)$. Psychological well-being of footballers play in youth steps does not differ by the statuses. About Wilks' Lambda test, there was not found a significant difference between the groups of ( $p>0.05)$ independent variable in terms of the dependent variable. Also, these research findings show parallelism with ours. Akbulut (2012) found differences between the statuses. According to these expressions, since each of the statuses has different missions, the forward aims to avoid the goals. These findings do not show parallelism with our findings.

With reference to ANOVA and Tukey test results, there was found the significant difference in the variable psychological wellbeing in the autonomy U16-U17 and U17-U19, environmental mastery U16-U17, individual development U16-U17 and U17-U19, life goals U16-U17 and psychological wellbeing sub-dimensions U16-U17 and U17-U19. The league level of these teams differs by autonomy, environmental mastery, individual development, life goals and psychological well-being. This result is consistent with the literature, for instance, in a recent study conducted by Reverberi et al. (2020) it was found that elite youth football players perceive significantly better relationships than sub-elite and amateurs and have significantly higher levels of psychological well-being. Besides, studies showed similar results with team sports athletes (Aydin et al., 2018).

There was found a significant difference in autonomy sub-dimension between 1-3 and 4-6 years $(\mathrm{p}<0,05)$ based on the league ranking. Gacar and Yanlic (2012), conducted a study 
with handball players and revealed that the self-esteem of players is at a high level. The selfesteem levels of the handball players who finish the league at top places are high. According to Anova and Tukey test results based on the monthly household income, there was a found significant difference between 1401 with 2000 and 3001 with 4000 income ranges $(\mathrm{p}<0,05)$. We can think about this finding that the difference should be accepted as normal if we suppose that the athletes with high income lead a good life. This finding can be commented as the psychological well-being of footballers in adolescence vary by the monthly income variable. Gülsen (2008) conducted a study and reported that the footballers who have a high income are more decisive and insistent.

Erguvan (2015) reviewed the level of intolerance to uncertainty and psychological wellbeing of the university students. With reference to the findings, there is a significant difference between autonomy, environmental mastery, individual development, positive relationships with others, life goal, self-acceptance dimensions and total psychological well-being levels. This difference is rooted in the students who perceive the income level as sufficient and the students who perceive the income level is insufficient. It is seen that environmental mastery, positive relationships with others, life goals, self-acceptance and total psychological well-being levels of students who perceive the income level is insufficient. With reference to this circumstance, as the income levels that the students perceive increase, their psychological wellbeing levels increase at the same time.

In this case, Kaplan, Shema, and Leite (2008) found that the high income is associated with the high environmental mastery, individual development, life goals and the selfacceptance. Ryyf et al., (1999) mentioned that socioeconomic level is associated with psychological well-being, self-acceptance, life goal, environmental mastery, individual developmental. Cenkseven (2004) and Anli (2011) pointed out that the positive relationships, self-acceptance and total psychological well-being of university students with high income are higher than the students with low income. Biswas, Diener and Tamir (2004) mentioned that as the income level increases, the targets and the living standards increase, the expectations differ. This is because highest level psychological well-being is not seen in the individuals with high income (Diener, Suh \& Oishi, 1997). A child of a family with low income is happier than the child of a family with high income.

\section{Limitations and future studies}

This study has some limitations. First, limited to the athletes playing football in the U16U17-U19 age group of Kocaeli Province in the 2016-2017 season. Second, this study is single- 
gendered. However, in Turkey female football has been popular recently. So, mutual comparison studies can be done with male and female football teams. Third, this study is crosssectional. So, quasi-experiment or longitudinal studies can be done. Future research may be designed with a different type of study design, instrumentation and sampling.

\section{Conclusion}

There was found a significant difference in ANOVA and Tukey tests that were applied for teams, league level, league ranking, monthly household income variables. Also, these findings support that the psychological well-being of footballers varies by league level, league ranking, and monthly household income. Also, there was not found a significant difference in ANOVA and Tukey tests applied just between the statuses. It can generally be said that participating in a regular physical activity and playing in a league affect the psychological wellbeing of the footballers.

For the other hand, the studies about raising young footballers should be conducted with the cooperation of the Department of Physical Education High School. Youth setup teams should establish supportive environments for the footballers. Harboring professionals in youth setups are especially important. The number of professionals who review the family relationships and also the number of professionals who provide psychological support ought to be increased. It is suggested to make some exercises to make the education similar in terms of the quality

\section{References}

Akbulut, A. K. (2012). Study of relations between decision-making, problem-solving skills and communication with their coaches of football players in professional and amateur leagues. [Unpublished Master's Thesis]. Ankara Gazi University. https://tez.yok.gov.tr/UlusalTezMerkezi/TezGoster?key=rcbWnuqW6HxCZ_98ARap gsgeobdD9SfL3xD7OxHZ-psOi34y6Ub3zfQt9Db5wtvF

Akın, A. (ed), (2008). Current Measurement tools used in psychology and education. Ankara: Nobel Publications.

Aktas-Ustun, N., Ustun, U. D., Isik, U., \& Yapici, A. (2020). Health belief regarding leisure time physical activity and nutritional attitude: Are they related in athletic and sedentary university students. Progress in Nutrition, 22 (1), 156-160. DOI: 10.23751/pn.v22i1S.9810 
Anli, G. (2011). Examining the relationship between self-handicapping and psychological well-being in terms of different variables [Unpublished Master's Thesis]. Sakarya University, Social Sciences Institute. https://tez.yok.gov.tr/UlusalTezMerkezi/TezGoster?key=rcbWnuqW6HxCZ_98ARap gnmGWEeAuRNq2T47ko45-UypH3Y0pJYkLQfNSbZ1dqxd

Arı, Ç., Ulun, C., Yarayan, Y. E., Dursun, M., Mutlu, T., \& Ustün, U. D. (2020). Mindfulness, healthy life skills and life satisfaction in varsity athletes and university students. Progress in Nutrition, 22. DOI: 10.23751/pn.v22i2-S.10561

Aydın, E., Birol, S, Ş., \& Temel, V. (2018). The determining of psychological well-being levels of athletes playing in university teams. International journal of human sciences, 15 (3). DOI: $10.14687 /$ jhs.v15i3.5236

Bayazit, B., Atabay, S., \& Uzuner, M. E. (2020). The Investigation of the Effect of Sportive Recreational Activities Applied to Secondary School Students on their Self-Esteem. Kastamonu Education Journal, 28 (4), 1770-1775. doi: 10.24106/kefdergi.3680

Biddle, S. J. H.,\& Mutrie, N. (2001). Psychology of Physical Activity: Determinants, Well Being and Interventions. London: Routledge.

Biswas-Diener, R., Diener, E. and Tamir, M. (2004). The Psychology of Subjective WellBeing. Daedalus, 133 (2), 18-26. https://watermark.silverchair.com//

Cenkseven, F. (2004). Examining the predictors of subjective and psychological well-being of university students [Unpublished doctoral dissertation]. Çukurova University Social Sciences Institute. https://tez.yok.gov.tr/UlusalTezMerkezi/TezGoster?key=Keh6sQzap4ZTp8dqWPIH1 N0gXgNA74NwZsy1STRZISD7VwuY_XJMUidhnWEjoW1h

Cirhinlioglu, F. G. (2006). The relationships among shame proneness, religious orientations, self-construals, psychological well-being within a university student group [Doctoral dissertation] Hacettepe University. https://tez.yok.gov.tr/UlusalTezMerkezi/TezGoster?key=biL2P3cCsPgUNjVdV2BsG L1Iehb6TZ85z0-KzSnRhyQtjK9406lb9fAa8LhuV5h6

Diener, E., Suh E., \& Oishi, S. (1997). Recent findings on subjective well-being. Indian Journal of Clinical Psychology, 24, 25-41. https://intranet.newriver.edu/images/stories/library/Stennett_Psychology_Articles/Rec ent\%20Findings\%20on\%20Subjective\%20Well-Being.pdf 
Dogan, T. (2006). The Investigation of the wellness of university students. Journal of the Faculty of Education, 30, 120-129. https://dergipark.org.tr/en/download/articlefile/87665

Edwards, S. D,. Ngcobo, H. S. B., Edwards D. J., \& Palavar K. (2005). Exploring the relationship between physical activity, psychological well- being and physical selfperception in different exercise groups. South African Journal for Research in Sport, Physical Education and Recreation, 27 (1), 75-90. https://hdl.handle.net/10520/EJC108797

Erguvan, F. M. (2015). An examination of intolerance of uncertainty levels and psychological well-being levels of university students [Master Thesis, Sakarya University Institute of Education Sciences]. https://tez.yok.gov.tr/UlusalTezMerkezi/TezGoster?key=WY5CM7tPNE2z_YM6pBu 0t4DepU-R4hkKj0FLX-WW8_xYFVf4_o0QNB6nvrgSCLpK

Eryilmaz, A. (2010). The relationship between using of subjective well being increasing strategies and academic motivation in adolescence. Clinical Psychiatry, 13, 77-84. https://jag.journalagent.com/kpd/pdfs/KPD_13_2_77_84.pdf

Gacar, A \& Yanlic, N. (2012). Examining the self-esteem levels of adolescent handball players aged 13-17 in terms of some variables. Journal of Sports and Performance Studies, 3 (2), 45-50. https://dergipark.org.tr/tr/download/article-file/190495

Gülsen, D. (2008). Analyzing the players who is playing in different division levels, the problem solving abilities of the soccer players according to league, education levels and sport age [Master Thesis, Çukurova University Health Sciences Institute]. https://tez.yok.gov.tr/UlusalTezMerkezi/TezGoster?key=ePX_SaJ0b35Gq45swKG31C HGJwwNknUldrfQCnF-mh7RQ8luAzZ1ZXuVZ3TQ9F0C

Gündüz, B., Capri, B., and Gökcakan, Z. (2012). Investigation of University Students' Burnout Levels. Dicle University Ziya Gökalp Faculty of Education Magazine, 38 (19), 38-55. https://dergipark.org.tr/tr/download/article-file/190495

Hassmen, P. K. (2000). Physical exercise and psychological well-being: A population study in Finland. Preventive Medicine, 30 (1), 17-25. DOI: 10.1006/pmed.1999.0597

Hunt-Shanks, T., Blanchard, C.,\& Reid, R.D. (2009). Gender differences in cardiac patients: A longitudinal investigationof exercise, autonomic anxiety, negative affect and depression. Psychology, Healthand Medicine, 14 (3), 375-385. DOI: $10.1080 / 13548500902866939$ 
Kaplan, G. A., Shema, S. J. \& Leite, C. M. (2008). Socioeconomic determinants of psychological well-being: The role of income, income change, and income sources during the course of 29 years. Annals of Epidemiology, 18, 531-537. DOI: 10.1016/j.annepidem.2008.03.006

Karasar, N. (2003). Scientific research method. Ankara: Nobel Publication Distribution.

Keyes, C. L. M, Shmotkin, D., Ryff, C. D. (2002). Optimizing Well-Being: The Emiprical Encounter of Two Traditions, Journal of Personality \& Social Psychology, 82 (6): 10071023. DOI: 10.1037/0022-3514.82.6.1007

Onur, B., Dönmez, A., \& Çelen, N. (2015). Child and adolescent development. İstanbul: Printing, İmge Bookstore.

Pehlivan, K. B. (2005). A study on teacher candidates' perceptions of communication skills. Primary education Online, 4 (2). https://www.ilkogretim-online.org/fulltext/2181596619966.pdf?1618826336

Reverberi, E., Dangelo, C., Littlewood, M. A., \& Gozzoli, C. (2020). Youth football players' psychological well-being: the key role of relationships. Frontiers of psychology, 11, 567776. DOI: $10.3389 /$ fpsyg.2020.567776

Ryan, R. M., \& Deci, E. L. (2001). On happiness and human potentials: A review of research on hedonic and eudemonic well-being. Annual review of psychology, 52 (1), 141-166. https://www.annualreviews.org/doi/pdf/10.1146/annurev.psych.52.1.141

Ryyf, C. D., Magee, W. J., Kling, K. C. \& Wing, E. H. (1999). Forging macro-micro linkages in the study of psychological well-being. In C. D. Ryff \& V. W. Marshall (Eds.). The self and society in aging processes. New York, NY: Springer Publications.

Scully, D., Kremer, J., Meade, M. M., Graham, R., \& Dudgeon, K. (1998). Physical exercise and psychological well-being: A critical review. British Journal of Sports Medicine, 32 (2), 111- 12 https://bjsm.bmj.com/content/bjsports/32/2/111.full.pdf

Seligman, M. E. P. (2002). Authentic happiness: Using the new positive psychology to realize your potential for lasting fulfillment. New York: Free Press.

Shuster, T. L., Dobson, M., Jauregui, M \& Blanks, R. (2004). Wellness Lifestyles I: A Theoretical framework linking wellness, health lifestyles, and complementary and alternative medicine. The Journal of Alternative and Complementary Medicine, 10 (2): 349-356. http://doi.org/10.1089/107555304323062347

Yavuzer, H. (2013). The first 6 years of your child with physical, mental and social development. İstanbul: Remzi Bookstore. 